\title{
The Impact of ICT on University Students' Academic Studies
}

\author{
Onyia, Mary N. \\ Deapartment of Curriculum Studies \\ Enugu State College of Education (Technical), Enugu-Nigeria
}

\section{Doi:10.5901/jesr.2013.v3n8p105}

\begin{abstract}
This study was carried out in university of Nigeria Nsukka to investigate the impact of ICTs on University Students academic studies. The study adopted a survey research method. The sample size is 300 students selected randomly from faculty of social science, University of Nigeria, Nsukka. Questionnaire was the instrument for data collection. Two research questions were developed to guide the study. Frequency and percentage were used to analyze the two research questions. The findings of the study reveal that ICT impacts at very high extent on university students' academic studies. The study also indicated that university students use ICTs to support and improve their academic studies at a very high extent.
\end{abstract}

Keywords: Information and Communication Technology, Universities students, Improvement, Academic studies.

\section{Introduction}

The rapid growth in Information and Communication Technologies (ICT) has brought remarkable changes in our contemporary society. The use of ICT is already indispensable in the area of education especially in tertiary and secondary schools. ICTs are the technologies used in conveying, manipulating and storing of data by electronic means. They provide an array of powerful tools that may help in transforming the present isolated teacher-centered and text-bound classrooms into rich, student-focused, interactive knowledge environments.

The direct link between the use of ICT in students' studies has been the focus of extensive literature during the last two decades. While some scholars believe that ICTs improve the students' study habit, others do not support this view. Inline with the above, Valasidou and Bousiou (2005) stated that students frequently use ICT resources especially internet for their studies, and that internet has huge impact in improving students' study habits. Leuven et al. (2004) against this view, stated that there is no evidence for a relationship between increased educational use of ICT and students' performance. In fact, they find a consistently negative and marginally significant relationship between ICT use and some student achievement measures. Still, in support of Valasidou and Bousiou (2005) Abdulla Y. Al-Hawaj, Wajeeh Elali and E.H. Twizell (2008) stated that ICT has the potential to transform the nature of education: where and how learning takes place and the roles of students and teaching takes place and the roles of students and teachers in the learning process. Karim and Hassan (2006) also noted the exponential growth in digital information has changed the way students perceive study and reading and in how printed materials are used to facilitate study.

Based on the extended use of ICTs in education, the need appeared to unravel the myth that surrounds the use of information and communication technology (ICT) as an aid to teaching and learning, and the impact it has on students' study habits and improvement to learning. Therefore, the present study aims to examine the impact of ICT on university students' academic studies. 


\section{Purpose of the Study}

The main purpose of this study was to investigate the impact of ICTs on University Students' studies. Specifically, the study investigated;

1. If university students use ICTs to support their studies

2. If ICT usage improves university students' studies

\section{Research Questions}

The following research questions guided the study:

1. Do university students use ICTs to support their studies?

2. Does ICT usage improve university students' studies?

\section{Materials and Methods}

The study was based on survey research design. The Researcher administered 300 questionnaires randomly to students of university of Nigeria, Nsukka. The administering of the questionnaire was personally carried out by the researcher and his research assistant. The return rate of the questionnaire yielded $100 \%$ return rate. The response of the questionnaire was analyzed using frequency and percentage.

\section{Results}

The results of the analysis are presented in the tables below

Table 1. Percentage distribution of respondents on the extent they use ICTs for supporting their academic studies. $\mathrm{N}=300$

\begin{tabular}{lcc}
\hline Response & Frequency & Percentage \\
\hline High extent & 160 & 53.3 \\
Very high extent & 110 & 36.7 \\
Low extent & 20 & 6.7 \\
Very low extent & 10 & 3.3 \\
\hline
\end{tabular}

From the above table, the result shows that $160(53.3 \%)$ of the respondents are of the view that they use ICTs at high extent in supporting their academic studies. While $110(36.7 \%)$ of the respondents are of the view that they use ICTs at very high extent in supporting their academic studies the respondents indicated that they use ICT for academic studies. These two indications are greater than the opinion of the respondents who stated that they use ICTs on low and very low extent which is $20(6.7 \%)$ and $10(3.3 \%)$ respectively. Therefore the result shows that students use ICTs at high extent in supporting their academic studies.

Table 2 . Percentage distribution of the respondents on the type of ICT resources that they use for their studies. $\mathrm{N}=300$

\begin{tabular}{llc}
\hline Response & Frequency & Percentage \\
\hline Internet & 220 & 73.3 \\
Cable TV & 2 & 0.7 \\
Resource CD/DVD & 8 & 2.7 \\
All of the above & 70 & 23.3 \\
\hline
\end{tabular}

From the above table, the result shows that $220(73.3 \%)$ of the respondents are of the view that they often use internet for their academic studies. While $70(23.3 \%)$ of the respondents are of the 
view that they use all the enlisted ICT resources (Internet, cable TV, resource CD/DVD) for their academic studies. The opinion of the respondents on this two is greater than the opinion on those who state that they use of Cable TV and Resource CD/DVD which is $2(0.7 \%)$ and $8(2.7 \%)$ respectively. Therefore the result shows that students often use Internet for supporting their academic studies

Table 3. Percentage distribution of the respondents on their frequency of using ICTs for academic studies. $\mathrm{N}=300$

\begin{tabular}{lcc}
\hline Responses & Frequency & Percentage \\
\hline Often & 80 & 26.7 \\
Very often & 190 & 63.3 \\
Rare & 30 & 10 \\
Very rare & - & - \\
\hline
\end{tabular}

From the above table, the result shows that $80(26.7 \%)$ of the respondents are of the view that they often use ICT for their academic studies; 190 (63\%) of the respondents are of the view that they very often use ICTs for their studies, while $30(10 \%)$ of the respondents are of the opinion that they rarely use ICTs for their academic studies. Therefore the result shows that students very often use ICTs for supporting their academic studies.

Table 4. Percentage distribution of respondents on the extent ICT facilitates their access to information. $\mathrm{N}=300$

\begin{tabular}{lcc}
\hline Response & Frequency & Percentage \\
\hline High extent & 50 & 16.7 \\
Very high extent & 220 & 73.3 \\
Low extent & 20 & 6.7 \\
Very low extent & 10 & 3.3 \\
\hline
\end{tabular}

From the above table, the result shows that $50(16.7 \%)$ of the respondents are of the view that ICT facilitates their access to information at high extent, $220(73.3 \%)$ of the respondents indicated that they use ICTs at high extent in supporting their academic studies. $110(36.7 \%)$ of the respondents are of the view that ICT facilitates their access to information at very high extent, while $20(6.7 \%)$ and $10(3.3 \%)$ of the respondents are of the view that ICT facilitates their access to information at low and very low extent respectively. Therefore the results show that ICT facilitate students' access to information at very high extent.

Table 5. Percentage distribution of the respondents on the extent ICT impacts their reading/studying. $\mathrm{N}=300$

\begin{tabular}{lcc}
\hline Response & Frequency & Percentage \\
\hline High extent & 94 & 31.3 \\
Very high extent & 166 & 55.4 \\
Low extent & 30 & 10 \\
Very low extent & 10 & 3.3 \\
\hline
\end{tabular}

From the above table, the result shows that $94(31.3 \%)$ of the respondents are of the view that ICT impacts their reading/studies at high extent, $166(55.4 \%)$ of the respondents are of the view that ICT impacts their reading/studies at very high extent. While $30(10 \%)$ and $10(3.3 \%)$ of the respondents are of the opinion that ICT impacts their reading/studies at low and very low extent respectively. Therefore the results show that ICT impacts on their reading/studies at very high extent. 
Table 6. Percentage distribution of the respondents on the extent ICT improves their studies. $\mathrm{N}=300$

\begin{tabular}{lcc}
\hline Response & Frequency & Percentage \\
\hline High extent & 70 & 23.3 \\
Very high extent & 210 & 70 \\
Low extent & 18 & 6 \\
Very low extent & 2 & 0.7 \\
\hline
\end{tabular}

From the above table, the result shows that $70(23.3 \%)$ of the respondents are of the view that ICT improves their studies at high extent, $210(70 \%)$ of the respondents are of the view that ICT improves their studies at very high extent, while $18(6 \%)$ and $2(0.7 \%)$ of the respondents are of the opinion that ICT improves their studies at low and very low extent respectively. Therefore the results show that ICT improves the university students' studies at very high extent.

\section{Discussion}

The main purpose of this study was to investigate the impact of ICTs on University Students Studies. The research seeks to find out if university students use ICTs to support their studies and if the use of ICT improves university students' academic studies.

From the results of the study, students indicated that they use ICTs at high extent in supporting their academic studies. This is evidenced from their response in table I above where $160(53.3 \%)$ and $110(36.7 \%)$, making a total of 270 out of 300 students stated that they use ICT resources at high and very high extent respectively in their academic studies.

Also, majority of the respondents stated that they mostly use Internet more than other ICT resources for supporting their academic studies. This is in-line with the view of Valasidou and Bousiou (2005) who stated that students frequently use Internet for their academic studies.

On the second research question which seeks to find out if the use of ICT improves university students' studies, the result shows that ICTs facilitates students' access to information at very high extent. This is evidenced from the response by $270(90 \%)$ of the respondents out of $300(100 \%)$ of the respondents, who stated that ICT facilitates their information access at high extent and very high extent respectively. Also, the students indicated that ICT impacts and improves their studies. This is evidenced from table 5 and 6 where the respondents indicated that ICTs impacts and improves their learning and studies at very high extent. The result was gotten from the opinion of $166(55.4 \%)$ of the respondents who were of the view that ICT impacts their reading/studies at very high extent (see table 5) and $210(70 \%)$ of the respondents who were of the view that ICT improves their studies at very high extent.

\section{Conclusion}

The findings of the study revealed that ICT has great impact on the university students' studies. The study also reveals that university students use ICTs to support and improve their academic studies.

\section{References}

Abudulla, Y., Al-Hawaj, W. E., Twizell, E. H. (Ed.) (2008). Higher Education in the $21^{\text {st }}$ Century: Issues and Challenges. Taylor \& Francis Group, London, UK.

Bataineh, R. F; Baniabdelrahman, A. A. (2005). Jordanian EFL students' perceptions of their computer literacy, International J.Educ. develop. Using Infor. Comm. Technol., (IJEDICT), 2(2), 35 50. Computers in Human Behavior, 17(2), 187-195.

DeBell, M., \& Chapman, C. (2006). Computer and Internet use by students in 2003 (NCES 2006-065). US Department of Education. Washington, DC: National Center for Education Statistics. 
Esen, B. K., \& Gundogdu, M. (2010). The Relationship between Internet Addiction, peer pressure and perceived social support among adolescents. The International Journal of Educational Researchers, 2(1), 29-36.

Garrison, D. R., Kanuka, H. (2004). Blended learning: Uncovering its transformative potential in higher education. Internet and Higher Education, 7.

John, A., Bargh, G. Katelyn, Y. A. Mckenna (2004). The Internet and Social Life. NewYork: Lawrence Erlbaun Associates Publishers.

Kraute, R., Patterson, M., Lundmark, V., Kiesler, S., Mukopadhyay, T., \& Scherlis, W. (2008). Internet paradox: A social technology that reduces social involvement and psychological wellbeing? American Psychologist, 53, 1017-1031.

Liu Z (2005). Reading behaviour in the digital environment: changes in reading behaviour over the past 10 years. J. Doc., 61 (6) 700-12.

Morahan-Martin, J. (1999). Women and Internet: promise and perils. Cyber Psychology and Behaviour, 3(5), 683-696. Morgan, C.T., 1956. An introduction to Psychology. McGraw-Hill book Co. Inc. N.Y., USA.

Ogbonnaya, N. I. (1997) Teachers' perception of the management and maintenance of instructional materials in secondary schools. Health Movement Education Journall. (1), 135-143.

Omogie, I. (1990). Problems of integrating educational technology into teachers' education in Nigeria. Review of Education 2, 26 - 34.

Onyeachu, J. A.(2006). Integration of ICT(s) in teaching and distance learning in Nigeria. A paper presented at 16th annual national conference of Technological Writers Association of Nigeria (TEWAN) and faculty of education, Abia State University, Uturu, Wednesday, $5^{\text {th }}-8^{\text {th }}$ December 2007.

Ramirez E. (2003). The impact of the Internet on the reading practices of a university community: the case of UNAM", Proceedings of the 69th IFLA General Conferences and Council, available at: http://www.ifla.org/IV/ifla69/papers/09e-Ramirez. pdf.

Schumacher, P. \& MorahanMartin, J. (2001). Gender, internet and computer attitudes and Experience, Computer and Human Behaviour., 17(1), 5-110. 
